Nigerian Journal Of Physiological Sciences 21 (1-2):67-70@ Physiological Society Of Nigeria, 2006

Available online/abstracted at http://www.biolineinternational.org.br/njps; www.ajol.info/journals.njps; www.cas.org

\title{
SEMEN ANALYSIS OF INFERTILE IGBO MALES IN ENUGU, EASTERN NIGERIA.
}

\section{W. C. NWAFIA, J. C. IGWEH ${ }^{1}$ and I. N. UDEBUANI ${ }^{2}$}

Department of Physiology, College of Health Sciences, Delta State University, Abraka- Nigeria. E- mail; waltercares 007 @ yahoo .com.

Department of Physiology ${ }^{1}$, College of Medicine, University Of Nigeria Enugu Campus, Nigeria.

School of Medical Laboratory Science ${ }^{2}$, University of Nigeria Teaching Hospital, Enugu, Nigeria

Summary: The semen samples of 1,110 (one thousand, one hundred and ten) Igbo males attending infertility clinic, aged between $30-50$ years were collected and analyzed. The specimens were collected and analysed in the microbiology laboratory of the University of Nigeria Teaching Hospital (UNTH) Enugu, Eastern Nigeria. The standard method of masturbation after 3-5 days of prior abstinence from sex before sample collection was applied. The samples were examined for semen volume and microscopically as a wet preparation for sperm motility, morphology and count. The semen volume result showed that $91.0 \%$ were normal. $6.3 \%$ sperm samples were motile. In the sperm count, only $7.3 \%$ had normal cells, $62.0 \%$ showed abnormal morphology. The aetiology of male infertility in the population studied seems to be related to the sperm count, motility and morphology but not volume. Racial factor seems to play no role and it is important to abstain from sexual intercourse some days before collection of semen for analysis.

Key Words: Infertility, Igbo Males, Eastern Nigeria, Semen Analysis

\section{Introduction}

Male infertility is a very devastating problem especially in the environment under study. hence determining the possible aetiology of the problem is very important. The importance attached to child bearing in the culture of the Igbos makes infertility a devastating problem. In some cultures, childlessness may cast a heavy shadow on the physiological and social adequacy of the female and diminish the social standing of the male partner (Harrison, 1979).

Often the females are held responsible for this problem. Whereas they are usually willing and ready to undergo medical investigations, attend infertility clinics and counseling, the males are often recalcitrant. It has been reported that $30 \%$ of infertility are due to problems in females, $30 \%$ male and $30 \%$ in combined male and female problems; while in $10 \%$ there is no recognizable cause (Ihankam, 1991). Many workers have defined infertility in many ways
(Harrison, 1979; Ryan, 1981; Ihankam, 1991). However; the common thing in all these definitions is the inability to achieve a pregnancy within a specified time.

The effects of male infertility and its attendant consequences are quite enormous and unquantifiable emotionally (Mening, 1980), particularly in the Igbo speaking areas of Nigeria where the only recognizable sign of manhood seems to be fertility. Male contribution to infertility has been documented to be as high as $55-93 \%$ in Enugu (Chukwudebelu, 1978). It is sad to note that this incidence of male infertility is assuming an alarming proportion in many parts of the developing world despite the development of new techniques of diagnosis and treatment. These new techniques are not yet easily accessible to the general population thereby leaving us with no choice than to still rely on the old method of managing our patients.

Causes of male infertility have been documented to include medical causes (Otubu, 
1998), congenital defects of the genitalia (Lyndon, 1994) etc. These when prolonged have been found to affect semen quality. Semen analysis has been noted to be the most important single test in the evaluation of male infertility (Larry and Stunct, 1991). Semen of infertile men have been severally investigated and documented in an attempt to establish the possible aetiology of male infertility (Chukwudebelu, 1978; Vaclav and Bruno, 1993; Lyndon et.al, 1994; Ezenyirioha and Ajaebili, 1994).

The investigation of the role of male factor in infertility in the area under study is still difficult for many reasons, which include cultural attitude of male chauvinism, which blames infertility on the female partner (Ezenyirioha and Ajaebili, 1994). The above reasons probably reflect the paucity of accurate information of male contribution to infertility in this part of Nigeria, thus underscoring the need for this study.

\section{Materials and Methods}

\section{a) Subjects}

One thousand, one hundred and ten $(1,110)$ males from the Igbo speaking tribe in Enugu Eastern Nigeria were involved in the study. They were attending various clinics for infertility in Enugu, Eastern Nigeria and were referred for laboratory analysis of their semen at the microbiology laboratory of the UNTH Enugu.

They were aged between 30-50 years and the duration of infertility ranged between 2-5 years. The parameters analysed were semen volume, sperm morphology, sperm count and motility.

b) Sample Collection.

The semen samples were collected aseptically by masturbation (Harrison, 1979) into sterile universal glass or plastic sterilene bottles. All the subjects were instructed to abstain from sexual intercourse for 3-5 days prior to the sample collection, (Vaclav and Bruno, 1993). The samples collected were all analysed within 10 minutes by the same senior laboratory scientists.

c) Semen Analysis

In the semen volume estimation, a standard measuring cylinder was used to compare side by side the cylinder containing the semen. The equivalent of the volume of the semen was read off from the standard cylinder. A wet preparation was mounted on the microscope and the sperm motility, count and morphology determined. Motility was determined by finding the percentage of motile sperm cells against dead cells. The total sperm count was determined for each sample using the improved Neubauer counting chamber by counting the squares of the central ruled area of the chamber and using the dilution factor, the calculation was made.

d) Statistical analysis

The results obtained were pooled together and the means recorded. From the number of specimens, the percentages were worked out and recorded.

\section{Results}

Seminal fluid samples collected from 1,110 men were analysed.

The majority of the subjects $(91 \%)$ had adequate semen volume, while only $9 \%$ (total) had abnormal semen volume $(7.3 \%$ hypospermia and $1.7 \%$ hyperspermia) (Table 1 ).

$62 \%$ of the subjects had abnormal morphology of their sperm cells, while $38 \%$ of the subjects had sperm cells with normal morphology (Table 2).

In the study of sperm motility, $93.7 \%$ (total) of the infertile males had sperm motility less than $50 \%$, while only $6.3 \%$ of the subjects had sperm cells of normal motility (Table 3).

In the distribution of sperm count, only $2.7 \%$ had normal count, $4.6 \%$ were oligozoospermic, $40.9 \%$ showed polyzoospermia while $51.8 \%$ (majority) had no sperm cells in their semen samples (Table 4).

Table 1: Distribution of Volumes

\begin{tabular}{lcc}
\hline Volumes (mls) & $\begin{array}{c}\text { Number of } \\
\text { Specimen }\end{array}$ & $\begin{array}{c}\text { Percent } \\
\text { age }(\%)\end{array}$ \\
\hline $\begin{array}{l}\text { Normospermia } \\
\text { (2-5mls) }\end{array}$ & 1010 & 91 \\
$\begin{array}{l}\text { Hypospermia } \\
\text { (<2mls) }\end{array}$ & 81 & 7.3 \\
$\begin{array}{l}\text { Hyperspermia } \\
(>5 \mathrm{mls})\end{array}$ & 19 & 1.7 \\
\hline
\end{tabular}

Table 2: Distribution of Morphology

\begin{tabular}{lcc}
\hline \multicolumn{1}{c}{ Morphology } & $\begin{array}{l}\text { Number of } \\
\text { Specimens }\end{array}$ & $\begin{array}{c}\text { Percentage } \\
(\%)\end{array}$ \\
\hline $\begin{array}{l}\text { Abnormal(>20 } \\
\% \text { abnormal } \\
\text { morphology) }\end{array}$ & 688 & 62 \\
$\begin{array}{l}\text { Normal (<20\% } \\
\text { abnormal } \\
\text { morphology) }\end{array}$ & 422 & 38 \\
\hline
\end{tabular}


Table 3: Distribution of Motility

\begin{tabular}{lcc}
\hline \multicolumn{1}{c}{ Motility (\%) } & $\begin{array}{c}\text { Number of } \\
\text { Specimen }\end{array}$ & $\begin{array}{c}\text { Percentage } \\
(\%)\end{array}$ \\
\hline $\begin{array}{l}\text { Normospermia } \\
\text { (50\% upwards) }\end{array}$ & 70 & 6.3 \\
$\begin{array}{l}\text { Hypospermia } \\
\text { (<2mls) }\end{array}$ & 515 & 46.4 \\
$\begin{array}{l}\text { Hyperspermia } \\
(>5 \mathrm{mls})\end{array}$ & 525 & 47.3 \\
\hline
\end{tabular}

Table 4: Distribution of Count

\begin{tabular}{lcc}
\hline Count $($ Cell/ml) & $\begin{array}{c}\text { Number of } \\
\text { Specimen }\end{array}$ & $\begin{array}{c}\text { Percentage } \\
(\%)\end{array}$ \\
\hline $\begin{array}{l}\text { Oligozoospermia } \\
\left(<20 \times 10^{6}\right)\end{array}$ & 51 & 4.6 \\
$\begin{array}{l}\text { Normozoospermia } \\
\left(20 \times 10^{6} \text { to }\right.\end{array}$ & 30 & 2.7 \\
$\begin{array}{l}\left.150 \times 10^{6}\right) \\
\begin{array}{l}\text { Polyzoospermia } \\
\left(>150 \times 10^{6}\right)\end{array}\end{array}$ & 454 & 40.9 \\
$\begin{array}{l}\text { Azospermia } \\
(\text { No cells })\end{array}$ & 575 & 51.8 \\
\hline
\end{tabular}

\section{Discussion}

This study on semen analysis of infertile males of Eastern Nigeria is yet another of the few reports on male infertility from this part of the country (Chukwudebelu, 1978; Ezenyirioha and Ajaebili, 1994) with a modification to involve only males from the Igbo speaking tribe living in the area. It was rather difficult or near impossible to get seminal fluid from normal subjects hence the lack of comparison of the results obtained with a control from the same environment. This is because of the age-long difficulty in convincing the average Nigerian male to produce semen for analysis especially if he has no fertility problems. This has also been reported by Ezenyirioha and Ajaebili (1994).

The adequate semen volume may be as a result of the 3-5 days sexual abstinence adopted in this study as recommended by Mortiner et al (1988) and Larry and Stunct (1991).

Although we did not record the specific type of abnormality in the morphology of the sperm cells, our result agrees with the reports of David et al (1972), Altken et al (1982), Mackleod et al (1989) and Larry and Stunct (1991), that semen of infertile males contains a higher percent of abnormal forms. However Larry and Stunct (1991) reported that morphology results could be affected by staining techniques, subjectivity of observation and the definition of the sperm malfunction. Hence, it may not be a good prediction of the fertility potential of a given semen sample.

W.H.O (1987) has established the normal percentage morphology to be $50 \%$. Our abnormal value of $62 \%$ is higher than the WHO recommendation and the $45 \%$ recommended by Larry and Stunct (1991). Hence the abnormal sperm morphology as observed in this study population may have contributed to the male infertility.

The reduced motility in this study agrees with similar reports by Mortiner et. al. (1988) and in the same population by Ezenyirioha and Ajaebili (1994) who noted that among the ingredients of normal semen quality with which pregnancy is likely to occur is a motility of $60 \%$. The documented causes of asthenospermia (a decrease in sperm motility below 60\%) by Ezenyirioha and Ajaebili (1994) are very common in this environment.

The oligospermia $(4.6 \%)$ found in this study does not agree with that reported by Ezenyirioha and Ajaebili (1991) in the same population who recorded a higher value of $63 \%$. However it is close to $16 \%$ documented by Mackleod and Gold (1951). This may probably be as a result of the 3-5 days abstinence method employed in this study. This is supported by the observation of Schwartz et al, (1979) that each day of sexual abstinence increases the sperm count in healthy sperm donors by 13 million cells $/ \mathrm{ml}$. It is however re-assuring that fertility has been reported in men with counts of less than 5 million (Yeates, 1978). The purported practicability and possibility of this in the study population is still very suspect. (Ezenyirioha and Ajaebili, 1991).

The $51.8 \%$ of azospermia recorded in this study is very significant. This is based on the observation by Mackleod (1951), Amelar et al (1973) and Derrick and Johnson (1974) based on the theory that lower limits for semen quantity of 20 million per milliliter of ejaculate have been established under which a pregnancy is unlikely to occur.

\section{Conclusion}

Results from this study suggest that seminal fluid volume plays little or no role in the aetiology of male infertility. The major problem seems to be motility of the sperm cells. There seems to be no racial difference in the causes of male infertility. The role of sexual abstinence before seminal fluid sample collection for accurate seminal fluid analysis is very important. 


\section{References}

Altken, R. S., Besr, F. S. M. and Richardson, D. N. (1982). An analysis of sperm functions in cases of unexplained infertility capacity. Fert Steril 30: 212-214.

Amelar, R. D., Dubin, L., and Walsh, P. C. (1977). Male infertility. In: Infertility in Male and Female. Churchill Livingstone, Edinburgh; pp 150- 153.

Chukwudebelu W.O. (1978). The male factor in infertility, the Nigerian experience. Int.J. Fert. 23: $238-240$.

David G; Bisson J.P; Jouannet P. (1972). Les tetraspermies. In: Sterile du male acquisition recents (Thibauit C: ed) Masson et at company Paris, pp 205-240.

Ezenyirioha, M. A. S and Ajaebili, J. P. C. (1994). Seminal Fluid characteristics of men attending an infertility clinic in EnuguNigeria. Orient J. of Med. 6 : 24-26.

Harrison A. (1979). Diseases of the testes. In: Principles of Internal Medicine $\left(9^{\text {th }}\right.$ ed). Houghton Mifflin Company, Boston, pp 1771- 1715.

Ihankam R. (1991). Infertility in males. In: Clinical Gynaecology $\left(15^{\text {th }}\right.$ ed). Churchill Livingstone. Edinburgh. Pp 17-19.

Larry, I. and Stunct, E. (1991). Infertility. In: Male Infertility St. Louis Mosby, pp 309 312.

Lyndon O, Bunge R.G (1994). Semen analysis, evidence for changing parameters of fertility potential Fert Steril 25: 503-505.
MackLeod, J. and Gold R. (1951). The male factor in fertility and infertility, part 11spermatozoa count in 1000 men of known fertility. Urology. 66: 436.

Macleod, J., Hoch, C., Kiss, M. and Litterson, C. (1969). Recovery of male fertility after sterilization nuclear radiology. J. Am. Med. Assoc. 187:637.

Mening, E. C. K. (1980). Emotional needs of the infertile couple. Fert. Steril 34:313.

Mortiner D, Cioil N. (1988). Semen analysis system in routine laboratory setting. Fert Steril. 50:960.

Otuba .J (1998) Infertility. Tropical J. Obs. and Gynae. 12:69.

Schwartz, O., Laplanehe, A., Jouannet, P., David, C. (1979). Subject variability of human semen with regards to sperm count, volume, fetal number of spermatozoa and length of abstinence. J. Rep. Fert. 57: 391396.

Vaclar, I. and Brumo, I. (1993). Infertility in males. In; Infertility Male and Female. Churchill livingstone. Edinburgh pp.318320.

W.H.O (1987) Laboratory manual for the examination of male fertility 6: 70-75.

Yeates W. K. (1978). Male in fertility (editorial) J. Roy. Soc. Med. 71:395.

Received: $6 / 3 / 06$

Accepted: $31 / 5 / 06$ 